\title{
The Challenge of Introducing Competency-Based Psychiatry Training in Spain
}

\author{
Jon-Inaki Etxeandia-Pradera ${ }^{1}$ - Daniel Martinez-Uribe ${ }^{2} \cdot$ Francisco Bellver-Pradas $^{1} \cdot$ Jose-Carlos Gonzalez-Piqueras $^{3}$. \\ Eduardo-Jesus Aguilar ${ }^{3}$
}

Received: 20 November 2019 / Accepted: 17 March 2020 / Published online: 7 April 2020

(C) Academic Psychiatry 2020

Despite some differences between countries, becoming a psychiatrist usually involves two consecutive phases: undergraduate medical education (medical school) and postgraduate medical education (psychiatry training or residency) [1]. Psychiatry training is essential for the psychiatrists of the future (who may have clinical, managerial, educational, and research duties) [2], as it provides them not only the tools (knowledge, skills, attitudes, etc.) but also real-life scenarios (with actual patients, families, colleagues, managers, resources, etc.).

In a world in constant change and full of uncertainties that have a direct impact on health systems, society demands health professionals who are flexible in adapting to the new times and challenges [3]. The Commission on Education of Health Professionals for the twenty-first century envisioned that the future of professional education will be shaped by adaptation of competencies to specific contexts, guided by transformative learning and interdependence in education; this vision requires a series of instructional and institutional reforms [4].

Competency-based training has been formulated as the best approach to the current social and healthcare challenges [5]. The World Federation for Medical Education (WFME) itself states, "Postgraduate medical education is the phase of medical education in which doctors develop competencies under supervision after completion of their basic medical qualification and is usually conducted according to specified regulations and rules" [6]. Several leading countries in medical education have already developed their own versions for

Jon-Inaki Etxeandia-Pradera jietxeandia@gmail.com

Hospital Clínico Universitario de Valencia, Valencia, Spain

2 CSMA Horta, Barcelona, Spain

3 University of Valencia-CIBERSAM, Valencia, Spain competency-based training of various medical specialties such as psychiatry: CanMEDS in Canada [7, 8], the Accreditation Council for Graduate Medical Education (ACGME) in the USA [9], and Core Psychiatry Training in the UK [10], for example.

Spain is part of the European Union (EU), where undergraduate psychiatric education in medical schools is set by a common framework (Bologna Process) for all member states of the union and other associated countries; in contrast, postgraduate training to become a psychiatrist is not so harmonized [11]. Directive 2013/55/EU of the European Parliament and of the Council establishes the recognition of professional qualifications obtained in different member states including psychiatry $[12,13]$, but each country is left responsible for organizing medical training within its territory through its own national program for every specialty. Significant differences have been reported between European countries regarding organization, contents, and evaluation of psychiatry training $[14,15]$. The European Union of Medical Specialists (UEMS) is a professional organization that seeks to promote in the EU a common framework for residency in the different medical specialties and advocates for competency-based training and evaluation [16].

In this context, the Spanish system resembles others in that it is based on a national program, which is drawn up by a national board of experts and requires compliance by all training units across the country. However, in contrast to the Canadian, US, and British systems, it does not have competency domains or a competency-based evaluation. The psychiatry residence system in Spain also shows two anomalies in contrast to most other European countries: it only lasts 4 years, and recognition of child and adolescent psychiatry as a distinct specialty is still pending [17].

All in all, competency-based training in psychiatry is yet to be developed in Spain. Our purpose is to discuss the challenge that this task represents for Spanish psychiatry, providing a rationale for our views through a strengths, weaknesses, 
opportunities, and threats (SWOT) analysis in order to offer a tool for further discussion and contributions from other professionals. Table 1 summarizes the SWOT analysis in schematic fashion.

\section{Strengths}

In our view, the main strength of residency training in Spain is the system widely known as MIR, which stands for Médico Interno Residente, literally, resident medical intern. Every year, medical school graduates are ranked by their performance on a national exam and then sequentially choose from the available residency training positions of the 44 medical specialties that are integrated into the Spanish National Health System [18]. The MIR system seeks to ensure transparency and equal opportunity to all applicants, and since its national expansion in the 1970 s, it has proven successful in improving residents' training and achieving high standards [19]. In 2019, a total of 6797 medical training positions were offered; 271 corresponded to psychiatry residency, which lasts 4 years and is conducted in officially authorized psychiatry training units.

Psychiatry training units in Spain are headed by the National Board of Psychiatry, dependent on the Ministry of Health and composed of renowned Spanish psychiatrists. All units must follow the national training program set by the board, which guarantees a common and mandatory framework [20]. Thus, eventual changes proposed by the board and introduced in the program would make a direct impact on psychiatry training all over Spain.

The fact that both the national board and training units do not have any formal ties to the university system makes them especially dynamic. Moreover, training units have considerable autonomy as long as they are not in conflict with the national program, so they can identify and adjust to new needs more rapidly than traditional and overly bureaucratic academic centers. This is of notable interest regarding the challenge of introducing competency-based training, as it demands flexibility from organizations and staff in order to incorporate innovative educational and assessment methods.

Since 2008, the Spanish training system recognizes the figure of multi-professional teaching units in various interdisciplinary healthcare areas; in the case of mental health care, residents of psychiatry, clinical psychology, and mental health nursing are integrated into these units, each one retaining its own program and tutors [21]. The first multi-professional mental health teaching unit to achieve accreditation was that of Murcia [22]; its positive outcome has served as an example for its extension to the rest of Spain. This interdisciplinary model presents a series of advantages for the implementation of competency-based training: it highlights the importance of competencies related to communication and teamwork, provides additional options to go deeper into some scientifictechnical competencies (e.g., psychotherapy, research), and opens up new possibilities for multidisciplinary competencybased assessment methods (e.g., $360^{\circ}$ evaluation).

We also highlight that Spanish psychiatry, through its two representatives in the Section of Psychiatry of the UEMS, has a strong presence in the international forums that are leading the transformation of training towards a model of competencies.

\section{Weaknesses}

Training in Spain relies heavily on tutor psychiatrists, who are responsible for planning, management, supervision, and
Table 1 Spanish psychiatry and the challenge of introducing competency-based training

\begin{tabular}{|c|c|}
\hline Strengths & Weaknesses \\
\hline The MIR system: success and transparency & The current national program (2008) is outdated \\
\hline \multirow{2}{*}{$\begin{array}{l}\text { Common and mandatory framework for all through a } \\
\text { national program }\end{array}$} & Lack of well-established recognition for tutors \\
\hline & Lack of specific training for tutors \\
\hline A consolidated National Board of Psychiatry & Dependence on heads' interest and leadership \\
\hline $\begin{array}{l}\text { Experienced and dynamic training units } \\
\text { Presence at international forums (e.g., UEMS) }\end{array}$ & $\begin{array}{l}\text { Lack of incentives for university-oriented psychiatrists } \\
\text { to get involved in training }\end{array}$ \\
\hline Opportunities & Threats \\
\hline $\begin{array}{l}\text { Competency-based training, an internationally } \\
\text { consolidated model }\end{array}$ & $\begin{array}{l}\text { Lack of legal support for introducing } \\
\text { competency-based training }\end{array}$ \\
\hline \multirow{2}{*}{$\begin{array}{l}\text { The case for accountability regarding all components } \\
\text { of the educational process }\end{array}$} & Socioeconomic differences between regions \\
\hline & The risk of denaturing the MIR system \\
\hline $\begin{array}{l}\text { Ongoing pioneer experiences in competency-based } \\
\text { training in Spain }\end{array}$ & $\begin{array}{l}\text { Literature about medical education goes under the } \\
\text { radar for most psychiatrists }\end{array}$ \\
\hline $\begin{array}{l}\text { Guidance in competency-based training by medical } \\
\text { education societies }\end{array}$ & $\begin{array}{l}\text { The risk of importing without a proper } \\
\text { contextualization to Spain's situation }\end{array}$ \\
\hline Existing research structures (e.g., CIBERSAM) & \\
\hline
\end{tabular}


evaluation of the whole process [19]. However, there is not a nationally established recognition for them in terms of time for supervision or extra pay. Similarly, there are neither nationally established requirements for being a tutor nor formal training courses for present and future tutors about their educational tasks. These aspects usually depend on decisions made independently by regional governments, thus varying greatly from one region to another.

The ongoing version of the national program of psychiatry, which is the base of current training in Spain, dates back to 2008 [23]. Although the term competency is cited 12 times in the text, in fact it is not a competency-based curriculum; the absence of a competency-based evaluation is especially telling. This leaves the system with tutors who are not familiar with the competency-based training model in their day-to-day practice, nor are they being trained for its future use. We consider that the lack of specific training for tutors is one of the main weaknesses of the current system, and these deficiencies will become even more evident when a competency-based curriculum is implemented.

Competency-based training requires that those who hold managerial duties take a leading role in implementing the model. Spain's psychiatry training units depend on each hospital's head of psychiatry, for whom training usually is not a top priority. This goes in line with the already documented lack of interest for training issues among Spanish psychiatrists [24].

As previously stated, residency training is done out of the university system and without formal ties to it. Thus, those psychiatrists who aim to pursue an academic career may feel training psychiatry residents is less interesting/profitable than dealing with undergraduate students. With no academic incentive, the residency system is at risk of not engaging psychiatrists who are keen on developing an educational role.

\section{Opportunities}

Arguably the first experience in competency-based medical training in Spain was the one at Cruces University Hospital, where the head of studies implemented in 2008 a competencybased training for all of its specialties (including psychiatry) $[25,26]$; the model was not specific for psychiatry but constituted a good starting point for future designs. Within the framework set by the national program, the multiprofessional mental health teaching unit of Murcia reflected on its mission and social responsibility. From there, the unit developed its own competency-based curriculum, setting a series of competencies and evaluable indicators for every training period as well as a competency-based assessment model [27].

The current national program of medical oncology, published in 2013, constitutes the first and unique national teaching program of any Spanish medical specialty totally focused on competency-based training [28]. Alcorcon University Hospital is also recognized for its groundbreaking work in competency-based training, such as the 2019 guidebook for the tutors of its different medical specialties [29]; although psychiatry is not among them, many of the principles and the know-how gained through their experience could be useful for psychiatry as well.

The Spanish Society for Training in Health Specialties (SEFSE-AREDA) is a scientific society whose members have been involved in these efforts for the introduction of competency-based training in the different medical specialties in Spain [30]. Members of this society give courses for tutors about how to train residents in this new model, produce scientific papers, and make relevant international literature on educational topics accessible, for example. Both the National Board of Psychiatry (regarding the design of a new national program) and psychiatry training units (regarding training of trainers) could benefit greatly from collaborating with SEFSEAREDA.

There is an increasing case for accountability across human organizations, which encompasses acknowledgment and assumption of responsibility for actions or decisions as well as the obligation to report, explain, and be accountable for resulting consequences. As competency-based training constitutes a language that makes the educational process explicit, evaluable, and ascertainable [31], its implementation suits perfectly these demands.

In the case of Spanish psychiatry, competency-based training may offer accountability to all four components of the educational process. First, patients and families would benefit from a model that places professionalism and patient safety at its core. Second, psychiatry residents would be guaranteed better supervision and feedback, in line with their traditional demands [32]. Third, tutors would have data as proof of their activities that may be used for recognition of their work. Last but not least is the healthcare system and its sustainability: taking into account that psychiatry training relies almost exclusively on the public sector, it is essential that it can show results in exchange for the money it gets from taxpayers.

Psychiatry is a medical specialty whose scientific-technical knowledge is diverse and often scattered (e.g., neurosciences, psychotherapy, psychopharmacology). Competency-based training offers a chance for integrating all these areas in a training framework that focuses on psychiatry resident's learning process and is based on professionalism and ethics [3]. This is consistent with the work of the Cambridge School led by Professor Berrios, who claims that psychiatry's raison d'être is the patient's well-being [33].

The international move toward competency-based training is an opportunity for Spanish psychiatry to be on par with leading countries in medical education and to do so with a model that is contextualized to both the country's and the 
specialty's reality and needs. Finally, we consider competency-based training in psychiatry to be a research area on its own. The Network Centre for Biomedical Research in Mental Health (CIBERSAM) integrates Spain's most prominent research groups and facilitates collaborative bonds between them [34]. As these groups are usually associated with hospitals that have psychiatry training units, this network offers the opportunity to conduct multicenter research on the said training.

\section{Threats}

The lack of a general regulatory framework in Spain that gives legal support for competency-based training in the different medical specialties is a big obstacle for starting new initiatives applied to psychiatry. Although the authorities of different countries started to adopt competency-based training frameworks nearly two decades ago, successive Spanish governments of different political affiliation have failed to introduce the required reforms.

While ongoing claims of budget limitations have always been an issue in Spain, especially since the last economic crisis, it should be highlighted that there are important social and economic differences between regions. Regional per capita incomes ranged from 18,174 up to 34,916 euros in 2018 [35], while regional governments' per capita spending in health care varied from 1153 up to 1710 euros in 2017 [36]. These differences, together with the varying grades of privatization implemented by some regions to their respective healthcare systems, contribute to resource inequalities both in clinical assistance and training [37].

Spanish health professionals, including psychiatrists, overwhelmingly support the current MIR system and favor its agreed update as long as it stays loyal to its spirit and past achievements. However, the MIR system is at risk of being denatured: as political parties control their regional strongholds, they may transform the current system into a cluster of regionally organized separate training systems, in which they can increase their control and power at the expense of losing a common framework [37].

Scientific literature that deals with medical education and training issues is usually in a circuit of journals that differs from those usually read by psychiatrists [38]. This means that current discussions and relevant research in this topic are typically under the radar for most specialists, despite their everyday practice having more to do with training psychiatry residents than with genetic tests that have little or none clinical applicability.

The fact that competency-based training has already been developed for psychiatry training in other countries seems to be a great opportunity. However, there may be the temptation and the risk of just copying what other countries have done, without proper contextualization to Spain's situation. Special attention should be paid not to make this mistake, as adaptation of competencies to specific contexts is essential in competency-based training.

In conclusion, we consider that the introduction of competency-based training represents both a great challenge and a great opportunity for Spanish psychiatry. The current MIR system has proven successful and offers a variety of assets that may constitute the basis for the future, such as a national board responsible for the official training program and experienced and dynamic training units. At the same time, several aspects need to be improved, most notably regarding tutors' recognition and training in order to help them toward this new educational model. While the task is not without threats, the international context seems favorable, and Spanish psychiatry could also benefit from incorporating pioneering competency-based training experiences in Spain, which could come from both psychiatry training units and other medical specialties.

Acknowledgments The authors would like to thank Julio Bobes, Jesus Moran-Barrios, Pilar Ruiz-de-Gauna, and Margarita Saenz-Herrero for their insight on the topic during the National Congress of Psychiatry held in September of 2019 in Bilbao.

\section{Compliance with Ethical Standards}

Disclosures On behalf of all authors, the corresponding author states that there is no conflict of interest.

\section{References}

1. Wijnen-Meijer M, Burdick W, Alofs L, Burgers C, Ten Cate O. Stages and transitions in medical education around the world: clarifying structures and terminology. Med Teach. 2013;35:301-7.

2. Hudziak JJ. Crisis in American psychiatric education: an argument for the inclusion of research training for all psychiatric residents. In: Zorumski CF, Rubin EH, editors. Psychopathol genome neurosci era. Arlington: American Psychiatric Publishing, Inc.; 2005. p. 203-28. Chapter xiii, 239 Pages.

3. Morán-Barrios J. Un nuevo profesional para una nueva sociedad. Respuestas desde la educación médica: la formación basada en competencias. Rev Asoc Esp Neuropsiq. 2013;33:385-405.

4. Frenk J, Chen L, Bhutta ZA, Cohen J, Crisp N, Evans T, et al. Health professionals for a new century: transforming education to strengthen health systems in an interdependent world. Lancet. 2010;376:1923-58.

5. Frank JR, Snell L, Englander R, Holmboe ES, on behalf of the ICBME Collaborators. Implementing competency-based medical education: Moving forward. Med Teach. Taylor \& Francis. 2017;39:568-73.

6. WFME. WFME Global Standards for Quality Improvement: Postgraduate Medical Education. The 2015 Revision. Copenhagen; 2015.

7. Frank J, Snell L, Sherbino J. CanMEDS 2015 Physician competency framework. Ottawa; 2015.

8. Royal College of Physicians and Surgeons of Canada. CanMEDS Objectives of Training in the Specialty of Psychiatry. 2015;1-15. 
9. ACGME. ACGME Program Requirements for Graduate Medical Education in Psychiatry. 2019;1-66.

10. Royal College of Psychiatrists. Core Curriculum for Specialist Core Training in Psychiatry. 2017;82, 86.

11. Gutiérrez-Fraile M, Franco D. La formación del médico psiquiatra en España: de los estudios de pregrado a la formación especializada. Rev Neuropsiquiatr. 2014;76:137.

12. Directive 2013/55/EU of the European Parliament and of the Council of 20 November 2013 amending Directive 2005/36/EC on the recognition of professional qualifications and Regulation (EU) No 1024/2012 on administrative cooperation through the Internal Mark [Internet]. Off. J. Eur. Union. 2013 [cited 2020 Jan 11]. Available from: https://eur-lex.europa.eu/eli/dir/2013/55/oj

13. Real Decreto 581/2017, de 9 de junio, por el que se incorpora al ordenamiento jurídico español la Directiva 2013/55/UE del Parlamento Europeo y del Consejo, de 20 de noviembre de 2013, por la que se modifica la Directiva $2005 / 36 /$ CE relativa al reconocimie [Internet]. 2017 [cited 2020 Jan 11]. p. 104040-60. Available from: https://www.mscbs.gob.es/fr/profesionales/ formacion/recoTitulosEuro/docs/2017RD_581_2017_BOE-A2017-6586.pdf

14. Brittlebank A, Hermans M, Bhugra D, Pinto M, Rojnic M, Andrea $\mathrm{K}$, et al. Training in psychiatry throughout Europe. Eur Arch Psychiatry Clin Neurosci. Springer Berlin Heidelberg. 2016;266: 155-64.

15. Baessler F, Riese F, Pinto Da Costa M, De Picker L, Kazakova O, Kanellopoulos A, et al. Becoming a psychiatrist in Europe: the title is recognized across the European Union, but what are the differences in training, salary and working hours? World Psychiatry. 2015;14:372-3.

16. UEMS. Union Européenne des Médecins Spécialistes - European Union of Medical Specialists [Internet]. [cited 2020 Jan 11]. Available from: https://www.uems.eu/

17. Jacobs BW, Barrett E, Klasen H, Robertson P, Vašková L, Šnircová E, et al. Child and adolescent psychiatry training in Europe. Underst Uniqueness Divers Child Adolesc Ment Heal. 2018:325-50.

18. Harris JE, Lopez-Valcarcel BG, Barber P, Ortún V. Allocation of residency training positions in Spain: contextual effects on specialty preferences. Health Econ. John Wiley \& Sons, Ltd. 2017;26:37186.

19. Tutosaus Gómez JD, Morán-Barrios J, Pérez Iglesias F. History of medical specialty training system in Spain and its teaching milestones. Educ Medica. Elsevier. 2018:229-34.

20. Orden SCO/2616/2008, de 1 de septiembre, por la que se aprueba y publica el programa formativo de la especialidad de Psiquiatría [Internet]. 2008. p. 37916-21. Available from: https://www.boe. es/eli/es/o/2008/09/01/sco2616

21. Real Decreto $183 / 2008$, de 8 de febrero, por el que se determinan y clasifican las especialidades en Ciencias de la Salud y se desarrollan determinados aspectos del sistema de formación sanitaria especializada. [Internet]. Spain; 2008 [cited 2020 Jan 11]. Available from: https://www.boe.es/eli/es/rd/2008/02/08/183

22. Navarro-Mateu F, Pujalte Martínez ML, Puerto Garriga A, MoránSanchez I, Ruiz Martínez AM. Las Unidades Docentes Multiprofesionales: una oportunidad de mejora en la formación sanitaria especializada. Gestión y Evaluación Costes Sanit. 2010;11:33-45.

23. Bobes J, Garcia-Portilla MP, Bobes-Bascaran M-T, Parellada M, Bascaran M-T, Saiz PA, et al. The state of psychiatry in Spain. Int Rev Psychiatry. 2012;24:347-55.
24. Etxeandia-Pradera JI, Martinez-Uribe D, Gonzalez-Piqueras JC, Bellver-Pradas F, Sanjuan J, Aguilar-García-Iturrospe EJ. Los psiquiatras españoles y su interés en la docencia una revisión de los congresos nacionales de la última década. A Coruña: SEFSE; 2018.

25. Morán-Barrios J. Un nuevo profesional para una nueva sociedad. Respuestas desde la educación médica. Análisis del proceso de formación sanitaria especializada basado en la adquisición de competencias y de su evaluación. [Internet]. 2015 [cited 2020 Jan 11]. p. 1-152. Available from: https://addi.ehu.es/handle/ 10810/18254

26. Hospital Universitario Cruces. Formación Especializada Hospital Universitario Cruces [Internet]. [cited 2020 Jan 11]. Available from: https://osieec.osakidetza.eus/formacion-especializada-cruces/

27. Unidad de Docencia, Investigación y Formación de Salud Mental. Red de Salud Mental de la Región de Murcia [Internet]. [cited 2020 Jan 1]. Available from: www.murciasalud.es/ unidaddocentesaludmental

28. Orden SSI/577/2013, de 5 de abril, por la que se aprueba y publica el programa formativo de la especialidad de Oncología Médica y los criterios de evaluación de los especialistas en formación [Internet]. Spain; 2013 [cited 2020 Jan 11]. p. 27751-84. Available from: https://www.boe.es/boe/dias/2013/04/13/pdfs/ BOE-A-2013-3937.pdf

29. González Anglada MI. Guía del Tutor de Residentes [Internet]. Hospital Universitario Fundación Alcorcón; 2018 [cited 2020 Jan 11]. Available from: https://www.comunidad.madrid/hospital/ fundacionalcorcon/file/3559/download?token=DZJLFKk7

30. SEFSE-AREDA [Internet]. [cited 2020 Jan 11]. Available from: https://sefse-areda.com/

31. Van der Vleuten CPM. Competency-based education is beneficial for professional development. Perspect Med Educ. 2015;4:323-5.

32. Gómez-Beneyto M, Montilla-Garcia JF, De Castro-Manglano P, Gay-Pamos E, González-Torres MA, Gutierrez-Fraile M, et al. La opinión de los residentes de psiquiatría sobre la formación que reciben. Actas Esp Psiquiatr. 2011;39:174-9.

33. Berrios GE. Towards a new epistemology of psychiatry. Buenos Aires: Polemos; 2011.

34. Salagre E, Arango C, Artigas F, Ayuso-Mateos JL, Bernardo M, Castro-Fornieles J, et al. CIBERSAM: ten years of collaborative translational research in mental disorders. Rev Psiquiatr y Salud Ment (English Ed. Elsevier; 2019;12:1-8.

35. Instituto Nacional de Estadística. Producto interior bruto por habitante. Año 2018 [Internet]. [cited 2019 Oct 30]. Available from: https://www.ine.es/dyngs/INEbase/es/operacion.htm?c= Estadistica_C\&cid $=1254736167628 \& m e n u=u l t i D a t o s \& i d p=$ $125473557 \overline{6} 581$

36. del Carmen Rodríguez Blas M. Estadística del Gasto Sanitario Público 2017: Principales resultados [Internet]. 2019 [cited 2020 Jan 11]. p. 1-15. Available from: https://www.mscbs.gob.es/ estadEstudios/estadisticas/docs/EGSP $2008 /$ egspPrincipalesResultados.pdf

37. Gonzalez-Torres MA. A look at the future of psychiatry from the life and work of professor José Guimón. Gac Med Bilbao. 2018;115:37-41.

38. Jones T, Hanney S, Buxton M, Burns T. What British psychiatrists read. Br J Psychiatry Cambridge University Press. 2004;185:251-7.

Publisher's Note Springer Nature remains neutral with regard to jurisdictional claims in published maps and institutional affiliations. 